\title{
Indonesian Female Peacekeepers Participation in United Nations Interim Forces in Lebanon (UNIFIL) during 2015-2017
}

\author{
By Gede Sumertha ${ }^{*}$,Herlina Juni Risma Saragih ${ }^{ \pm} \&$ Sarah Astried $^{*}$
}

\begin{abstract}
This research is constructed in order to study and to analyze Indonesian female peacekeepers participation in United Nations Interim Forces in Lebanon (UNIFIL) during 2015-2017. The research is using qualitative methods and mechanisms and data were collected through interviews, observations, questionnaires, and documentation studies. The results of the research indicated that Indonesian female peacekeepers participation in Lebanon (UNIFIL) was increasing to deploy every year, but still had limited involvement in United Nations (UN) mission due to some obstacles on recruiting, and posting in area operation.
\end{abstract}

Keywords: female peacekeepers, United Nations, peacekeeping mission, Indonesia, UNIFIL

\section{Introduction}

United Nations (UN) peacekeeping mission is collective action committed to preserve world peace and security (United Nations 2008, p. 24). It involves various forces including military, police, and civilian. Following its development, the UN also put their concern on gender perspective in the peacekeeping missions. It is reflected on the adoption of UNSC Resolution No. 1325 Year 2000 regarding Women, Peace and Security. The resolution signified that gender perspective in peacekeeping mission is something essential considering multidimensional impact at the conflicting area. It encouraged UN Member States to increase female participation in the peacekeeping missions which focused on participation, protection, assistance, and recovery (Geuskens 2014).

The paper focuses on participation of Indonesian female peacekeepers especially in the United Nations Interim Forces in Lebanon (UNIFIL) year 20152017. Indonesian female peacekeepers in this regard are as military officers and troops. Thus, the paper addresses a research questions on "how is the participation of Indonesian female peacekeepers in UNIFIL year 2015-2017?" We aim to analyze the participation of Indonesian female peacekeepers in UNIFIL at the above period considering Indonesia as the top ten of biggest troops contributing country (United Nations 2018). It is necessary whether the participation already put gender perspective or not.

\footnotetext{
*Senior Lecturer, Faculty of National Security, Indonesia Defense University, Indonesia. ${ }^{ \pm}$Lecturer, Faculty of Defense Management, Indonesia Defense University, Indonesia.

*Research Fellow, Department of Defense Diplomacy, Indonesia Defense University, Indonesia.
} 
In general, Indonesia's participation in the peacekeeping mission has started since 1957 by sending troops for United Nations Emergency Force (UNEF) in Sinai, Egypt (PMPP TNI 2011, p. 3). However, the first female deployment was officially sent in 2008 for United Nations Organization Mission in the Democratic Republic of the Congo (MONUC). Indonesia's contribution in the peacekeeping mission was mandated in Indonesia's Constitution at the Preamble article which stated that Indonesia will commit to participate in world peace and security. It is also in line with the principle of Indonesia's "bebas aktif" (independent and active) foreign policy that upholds state's sovereignty, thus, also implement nonintervention principle.

The paper focuses on participation of Indonesian female peacekeepers especially in the United Nations Interim Forces in Lebanon (UNIFIL) year 20152017. Thus, the paper addresses a research questions on "how is the participation of Indonesian female peacekeepers in UNIFIL year 2015-2017?" The aim of the research, to analyze the participation of Indonesian female peacekeepers in UNIFIL at the above period considering Indonesia as the top ten of biggest troops contributing country (United Nations 2018). It is necessary whether the participation already put gender perspective or not.

Further, Indonesia was holding vision of 4,000 peacekeepers that shall be achieved in period of 2015-2019 (Capie 2016). Fortunately, to accomplish this mission, Indonesia has established a special team to coordinate related to Indonesia's contribution in UN peacekeeping operations. The team was established in 2011 based on Presidential Regulation No. 85, namely TKMPP (Coordinate Team for Peacekeeping Mission/Tim Koordinasi Misi Pemeliharaan Perdamaian). The team consisted of eight Ministries and state institution with Ministry of Foreign Affairs as the Officer in Charge and Ministry of Defense as the Member. They coordinate regularly for once a month on every detail of Indonesia's contribution to the UN Peacekeeping missions as well as to consider how Indonesia will participate, how to increase and anticipate the participation considering the actual strategic environment at the mission area. Regarding this vision, Indonesian female peacekeepers are also the part to participate. Moreover, operationally, Indonesia has established PMPP-TNI (Indonesia National Defense Peacekeeping Forces Center/Pusat Misi Pemeliharaan Perdamaian-Tentara Nasional Indonesia) who responsible for the preparation of Indonesia's participation started from recruitment process, pre-deployment training, the departure, until the forces are back to Indonesia (PMPP TNI 2011, p. 235). TKMPP and PMPP-TNI are coordinating to set and implement the strategy of peacekeeping forces deployment, including to South Lebanon.

The reason for choosing UNIFIL is because the biggest female peacekeepers were deployed by Indonesia in South Lebanon. 2015 was selected as the starting point of this research considering the first year of Indonesian vision of 4,000 peacekeepers while 2017 is the final period that signified the role of Indonesian female peacekeeper in community outreach activity.

The outline of this paper is started with introduction and followed with literature review of participation, concept of UN peacekeeping mission and gender mainstreaming. Then, the research methodology is outlined to cover our research 
design, data collection and analysis. Our findings are discussed in four areas including preparation stage, obstacles, female in quantity and activities. Finally, conclusions and recommendations are drawn.

\section{Participation}

Cohen and Uphoff (1980) revealed that participation is not merely something that can be calculated in quantity (Cohen and Uphoff 1980). It is whole aspects that involved in the participation itself such as the individual/actor, process, and other features that support the process. They mentioned that participation is divided into 4 main types; 1) Participation in decision making, 2) Participation in implementation, 3) Participation in benefits, and 4) Participation in evaluation (Cohen and Uphoff 1980). The involvement of someone in formulating alternative policies or giving consideration for a certain issue could be identified as participation in decision making, but not limited to those activities. In kind of participation in implementation, it is more about the utilization of resources to run a program, policy or others. While in kind of benefits, participation refers to some kinds of involvement that are seen from the output or result that are going to be obtained or about the percentage of success. Finally, participation in evaluation means that contribution to assess the implementation of program.

Not limited to perspective from Cohen and Uphoff, Arnstein presented about eight levels of citizen participation. It explained the degree of participation start from non-participation, degrees of tokenism, and degree of citizen power as the highest level. The eight levels are: 1) Manipulation, 2) Therapy, 3) Informing, 4) Consultation, 5) Placation, 6) Partnership, 7) Delegated Power, and 8) Citizen control (Norad 2013). This research focused on participation explained by Cohen and Uphoff. To identify the participation, some aspects are needed to be concerned such as actors, objectives, available information, and the output of participation.

\section{UN Peacekeeping Mission}

UN peacekeeping mission is part of United Nations which carried out a mandate to help countries torn by conflict in creating peace conditions (United Nations 2012, pp. 10-20). The UN has started the peacekeeping mission since 1948 but the creation of special department of peacekeeping operations (DPKO) was made in 1992. Those activities related to peacekeeping operations are Security Council's responsibility since they have primary concern for ensuring international peace and security.

UN peacekeeping missions are implemented based on three basic principle, they are: 1) Consent of the parties, 2) Impartiality, and 3) Non-use of force except in self-defense and defense of the mandate (United Nations 2008, pp. 31-40). The mission can only be done by obtaining consent/permission from the conflicting parties. Peacekeeping forces also have no standing position to all conflicting 
parties. Lastly, the use of force is only allowed under defense conditions and under official mandate from Security Council.

The UN has no standing military or police forces of its own. They are coming from member states contribution for each operation. In running the mission, peacekeepers are not only military forces but also police and civilian. The UN admitted the important role of civilians in the peacekeeping operations to support confidence building, conflict management, negotiation and reconciliation (United Nations 2012). This research captured Indonesian military forces in the mission.

\section{Gender Mainstreaming}

Gender mainstreaming is main global strategy that created to promote gender equality (United Nations 2002, pp. v-vii). It was discussed in the fourth World Conference on Women in Beijing, 1995. In its development, ECOSOC adopted resolution of gender mainstreaming in 2001 when the discussion has conducted in the General Assembly of 2000. ECOSOC define gender mainstreaming as:

"...the process of assessing the implication for women and men of any planned action, including legislation, policies or programmes, in all areas and at all levels. It is a strategy for making women's as well as men's concerns and experiences an integral dimension of the design, implementation, monitoring and evaluation of policies and programmes in all political, economic and societal spheres so that women and men benefit equally and inequality is not perpetuated. The ultimate goal is to achieve gender equality." (United Nations 2002)

Gender mainstreaming does not mean to establish a separate project between male and female. It is more about integrated part from all of activities and promotes equal opportunities (Schouten and Dunham 2012). This concept has already adapted as well to the UN Security Council through resolution number 1325 on October 2000 which also gave a concern to gender perspective in peacekeeping operations. In 2006, DPKO has published directive policy related to gender equality in peacekeeping mission to ensure gender perspective in each policy and activities including structure of organization, resources, and budget (Pramasatya 2015). It cannot be achieved without institutional commitment to implement.

\section{Methodology}

The research was conducted in qualitative study between July-December 2018 by using interview as one of the instruments. A total of 5 state ministries and/or institutions in Jakarta and Bogor who played substantial role in Indonesia's contribution in UN Peacekeeping were selected by the research team. 13 participants were interviewed with purposive sampling. All interviews were conducted directly (face to face) and digitally recorded with consent of the interviewees. List of questions is provided for guiding the interviews but still open 
for further discussion. Thus, we used semi-structured interview with open-ended questions. During the visit to official state institutions, data related to Indonesian peacekeepers record were also obtained. They provided quantity of Indonesian peacekeepers per year and classified based on the missions.

Apart from the interviews, public and institutions' documents as well as official website information are collected as necessary. Finally, the collected data are verified through triangulation. As explained by Miles and Huberman, triangulation is necessary to support the data validity check (Miles et al. 2014). In this regard, the research used triangulation of sources and methods to verify the obtained information. Further, the data collections were analyzed by interactive model which includes data condensation, data display, and conclusions. Data was selected, focused, and simplified. Then, it displayed in various type such as text, table, and figure. After an interactive process, it came to the conclusion of the research.

\section{Peacekeeping Forces Preparation}

The preparation stage to send Indonesian female peacekeepers is started from recruitment, training and deployment. The implementation of peacekeeping operations is enshrined in Indonesia National Defense Commander Regulation Number Per pang/80/XII/2009. The process involved three leading actors; they are Indonesia National Defense Headquarter (Markas Besar TNI), Force Headquarters, and Indonesia National Defense Forces Peacekeeping Center (Pusat Misi Pemeliharaan Perdamaian Tentara Nasional Indonesia - PMPP TNI). In the preparation process, peacekeeping center is holding socialization to disseminate information concerning peacekeeping mission including general task and function, evaluation from the previous contribution, and selection process that will be taken forward. The socialization is done right after the issuance of official directive letter about recruitment from Indonesia National Defense Headquarter. Unfortunately, it is only socialized to the army forces as the main body in Task Force of Mechanic Infantry and Combat Battalion (PMPP TNI 2011, p. 238).

As the selection process, military forces both male and female must follow the tests such as medical fitness (mental and physical), English capability based on military ranks/position and kind of individual assignment, driving capability, and ability to operate computer. In an interview with Vice Commander of PMPP TNI, he confirmed that all the selection processes are conducted without any differentiation between male and female, they follow all terms and conditions.

However, to recruit more female, Indonesia is still facing some difficulties. It cannot be denied that masculine perspective still dominated military world (Lopes 2011, p. 2). Married females are still associated with domestic affairs such as managing household, taking care children and husband. Meanwhile, peacekeeping mission also need female contribution since the development of peacekeeping operations (United Nations 2008, p. 24). Victims of conflict are diverse with different sex, needs, and impact experiences. Gender-based violence was also happened to the victims in conflicting area including rape (United Nations 2003, p. 
1). Indonesian female peacekeeper, in an interview with the author, conveyed that female victims or ex-combatants tend to be reluctant to share information or their own experience with male forces because they might not comfort with. Therefore, women and girls in conflict area are needing certain approach to be embraced and empowered. The interview with representative of Officer in Charge for TKMPP revealed that Indonesia have many female peacekeepers who are interested to join the mission. Therefore, he suggested to create pool of candidate for those interested to be female peacekeepers and continue with capabilities injection to support their preparation. Through that way, he expected that Indonesian female peacekeepers could give contribution in strategic/substantial position in the mission, not only as a troop.

\section{Obstacles in Recruiting More Indonesian Female Peacekeepers}

Individual capacity is not a major reason to the limited participation of Indonesian Female Peacekeepers. Previously, language capacity of female forces was assumed as the main reason of limited participation. Most of candidates are failed when it comes to language selection. PMPP TNI confirmed that they have informed this requirement prior to the selection so that every candidate able to prepare their capability. An interview with a Researcher of Centre for Strategic and International Studies (CSIS) Indonesia conveyed that the problem of UN language capability could be solved through early training. ${ }^{1}$ However, female officer in Indonesia air force confirmed that early training for languages is not provided by PMPP TNI but through separate programs in each Indonesia National Defense Forces (TNI). The training is also not provided specifically for peacekeeping preparation rather to support military forces in running their assignment. $^{2}$

Apart from language capability, the limited participation of Indonesian Female Peacekeepers is more likely happened due to the limited quantity of female in Indonesia National Defense Forces (Tentara Nasional Indonesia). According to Director of International Security and Disarmament (Ministry of Foreign Affairs) the quantity of female military forces in Indonesia is about 3-4\% (Anya 2018). It gave logical consequences into the reluctance of senior military officers to permit their female officers in joining peacekeeping selection. In an interview with Vice Commander of PMPP TNI, female officers are needed in some districts to deal with job position as assigned for them. He told that the job might impossible to be replaced by other staff or alternatively required to employ other females from other corps/districts. When females are following the selection stages, it means that females will leave their position for temporary and it becomes concern for some of senior military officers. However, he also said that some military officers are very supportive for their females. These conditions led us to the assumption that this military world is still giving certain constrain to female in order to empower their self and gain better career achievement. Masculinism is enshrined

\footnotetext{
${ }^{1}$ Interview with Fitri Bintang Timur in Jakarta, Indonesia, 14 September 2018.

${ }^{2}$ Interview with Major Nani Kusmiyati in Jakarta, Indonesia, 25 November 2018.
} 
in the military world, including in Indonesia. Some perceptions are arising about female participation, senior officer experienced that military operations are more complicated with female involvement. They would find different routines, needs, and approach with male forces. In line with this perception, authors found that some senior officers might not too familiar on how to treat female forces in their group with kind of character and need differences.

Moreover, the obstacles not only coming from the limited number of female forces but also condition that given by the institution which obligated female to get written permission/consent from husband (PMPP TNI 2011). This is unique condition in Indonesia and not specifically regulated by the United Nations. Vice Commander of PMPP-TNI confirmed that this condition is essential since female (mainly the married female) is the biggest support system in family for taking care children and to be a housewife. This is Indonesian value that still creates a concern for stakeholders in preparing female peacekeepers. The interview with Indonesian female peacekeepers revealed that military females are lucky if the husband is kind of supportive partner or understand about military activities. It would support females to develop their career, to get new experiences, and to give contribution in the mission as well as for Indonesia. An investigation showed that military requirement in this matter is different with Indonesian Women Police. As per interview session with Indonesian Police Officer (2018), she said that Indonesian Female Police do not have to submit written permission/consent from husband. This different policy might need further discussion in military institution to find alternative that not violate Indonesian values in employing female peacekeeper to UN Mission, including UNIFIL.

\section{Quantity of Indonesian Female Peacekeepers in UNIFIL 2015-2017}

Apart from the above-mentioned obstacles, the quantity of Indonesian female peacekeepers was increasing annually in a gradual stage. In 2015, 23 out of 29 Indonesian female peacekeepers are deployed to UNIFIL. It increased about $26 \%$ from previous deployment to UNIFIL became 29 female peacekeepers. Slowly, it increased again in 2017 became 48 female peacekeepers (Figure 1).

Figure 1. Quantity of Indonesian Female Peacekeepers in UNIFIL 2015-2017

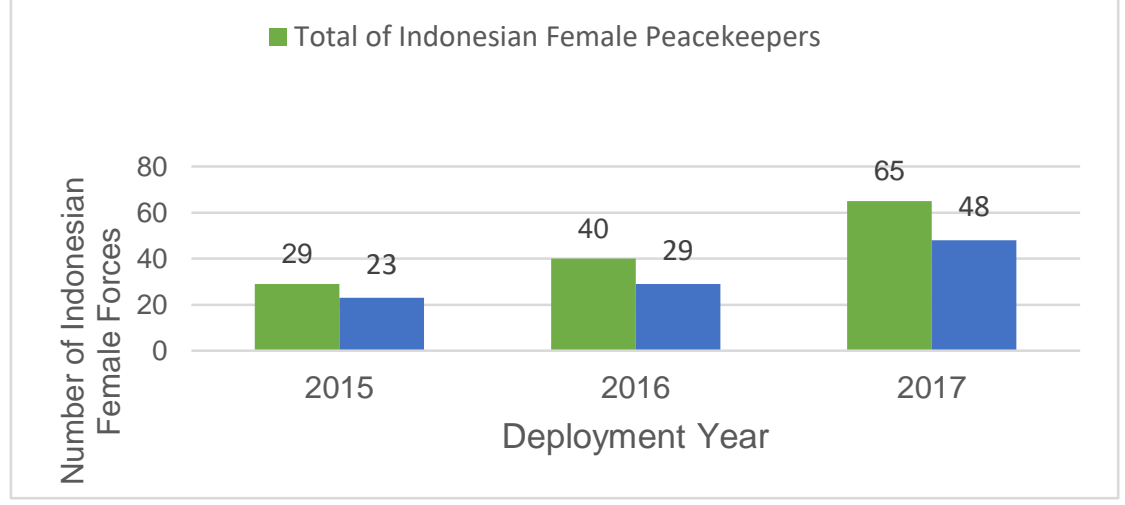


As of 2015-2017, 100 out of 134 Indonesian female peacekeepers are deployed to UNIFIL. It signifies more than $50 \%$ of them are selected to be posted in South Lebanon. It was deployed with some considerations. In an interview with female army, Major Erna Nuraeni, mentioned that UNIFIL is a "relative" safe mission ${ }^{3}$. It cannot be categorized as totally "safe mission" because the situation might be changing surprisingly. As per implementation report prepared by one of Indonesian female peacekeeper by 2016 , there were some highlighted incidents in Lebanon such as mass demonstration, road blocking by society, internal conflict in Ain El-Hilweh refugees camp, suicide bomb attack in Beirut, rocket launching from South Lebanon to Israel and its counterattack, Improvised Explosive Device (IED) bomb attack, etc.

PMPP TNI admitted that they also consider security factor in the mission for female deployment. From the above increasing number of Indonesian female peacekeepers in UNIFIL 2015-2017, it needs to find whether they are employed in substantial position or still in supporting unit under the mission. Substantial position in this matter means they are in military observer and military staff. After done a research about Indonesian female peacekeeper in UNIFIL 2015-2017, it was found that most of Indonesian female peacekeepers are posted as the Contingent troops and small number in the military staff position.

\section{Positions of Indonesian Female Peacekeepers in UNIFIL 2015-2017}

Military contributions in the peacekeeping operations are divided into three main components: Military Observer, Military staff, and Contingent troops (United Nations 2006, pp. 2-3). Specific for the UNIFIL, participation of Indonesian female peacekeepers can be seen in those components except military observer. Indonesia in UNIFIL mission has no military observer representative since Indonesia has no diplomatic relations with Israel. However, Indonesian female peacekeepers have stepped their role in military observer for Monusco in Congo. Indonesian female air force, Major Ratih Pusparini, was one of them. She was the first female peacekeeper deployed by Indonesia in $2008^{4}$. Her contribution to the mission was a milestone for Indonesia since she able to survive in a small team with different countries, different region compared to contingent, different cultures, and even with special tasks as an observer. She was the only one female in a team that consisted of six personnel. Her active contributions realized her awareness and understanding that female contribution is highly needed in conflict area. Females are needed to open an access to create a gender-friendly mission, get some information such as sexual violations, women and children needs, and some stories that could not be told to male forces (Allison 2015).

Moreover, as an Indonesian female, the inherent culture is to be friendly force. This is one of the reasons why Indonesian peacekeepers, including females, are one of local society favorites. To be a military observer means that they have more capacity either in language proficiency, military analysis, and mental

\footnotetext{
${ }^{3}$ Interview with Major Erna Nuraeni in Jakarta, Indonesia, 12 September 2018.

${ }^{4}$ Interview with Lieutenant Colonel Ratih Pusparini in Jakarta, Indonesia, 6 September 2018.
} 
strength. ${ }^{5}$ Generally, they are military personnel who at least ranked in Captain or Major. Their experience is needed considering they have to do some activities such as foot patrol, collecting information, observation, monitoring, analysis, and reporting the socio-economy as well as security situation in the Area of Responsibilities. Unfortunately, position of military observer for Indonesian female has been vacuumed since the last deployment of $2010^{6}$. According to an interview, it was happened due to this position is assumed as dangerous field for female. Vice Commander of PMPP TNI also confirmed that it was adjusted with requests from the UN. After that period, Indonesia never sent female military observer anymore and started to send again by 2018 to Congo. TKMPP considered that they will deploy more female if personnel meet the UN requirements and pass all the selection process. However, Indonesia's commitment to increase female participation shall be followed by some early actions to prepare female, not only by encouraging female through motivations and limited socialization.

Apart from that, Indonesian female peacekeepers in UNIFIL are posted in two military components; these are military staff and contingent. Technically, military staff is part of Contingent, but they work individually either in force headquarters or other special position that integrated with civilians' staff. Different with military staff, Contingent troops work in group for vary units such as infantry, aviation, engineers, so on. In UNIFIL, as of 2015-2017, Indonesian female peacekeepers in Contingent are posted in Mechanic Battalion Task Force, FHQSU (Force Headquarter Support Unit), MPU (Military Police Unit), FPC (Force Protector Company), MCOU (Military Community Outreach Unit), and Level II Hospital. Based on data acquired from PMPP TNI as of September 2018, during the abovementioned period, distribution of Indonesian female peacekeepers position in Contingent is as follows (Figure 2).

Representative of TKMPP Officer in Charge in an interview with author confirmed that Indonesia intended to focus in increasing female participation as military observer and military staff. Both positions are important as requested by the United Nations to all of UN Member States in achieving 15\% gender target for military in peacekeeping. Military institutions need to take some actions forward, not only encourage their female officers but also provide real supports include education and gender policy. Indonesia still has no gender policy that clearly state regarding its contribution to the peacekeeping. The institutions still focus on the number to achieve 4,000 peacekeepers but not supported by gender policy. In reference to UNSC Resolution No. 1325 year 2000, Indonesia attempted to actualize it in stages despite total implementation. Difficulties to recruit more female shall be overcome through mindset improvement. It would be hard if masculine perspective still dominates the military world. Therefore, to talk about female as first commander and other strategic position is still something that needs serious strategy and policy for Indonesia.

\footnotetext{
${ }^{5}$ Interview with Lieutenant Colonel Ratih Pusparini in Jakarta, Indonesia, 6 September 2018.

${ }^{6}$ Interview with Colonel Aldrin Petrus Mongan in Bogor, Indonesia, 3 October 2018.
} 
Figure 2. Distribution of Indonesian Female Peacekeepers Position in Contingent under UNIFIL Mission (2015-2017)

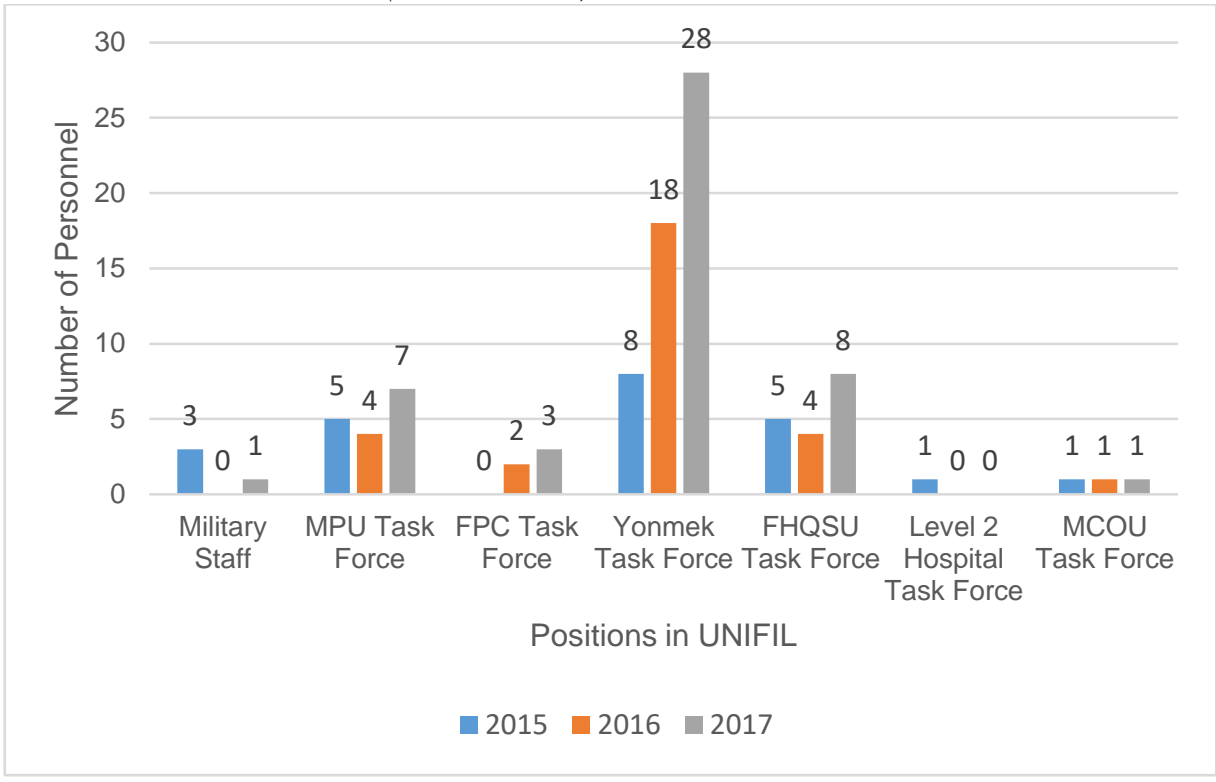

Indonesian contribution in UNIFIL is unique realizing that military forces either from army, navy, and air forces are present in the mission. It was confirmed by Head of Section for Peaceful Mission, Ministry of Defense that complete military districts does not always happened in every UN Mission. As of 20152017, the composition of military origins for Indonesian female peacekeepers in UNIFIL can be seen in Figure 3.

Figure 3. Composition of Military Districts for Indonesian Female Peacekeepers in UNIFIL (2015-2017)

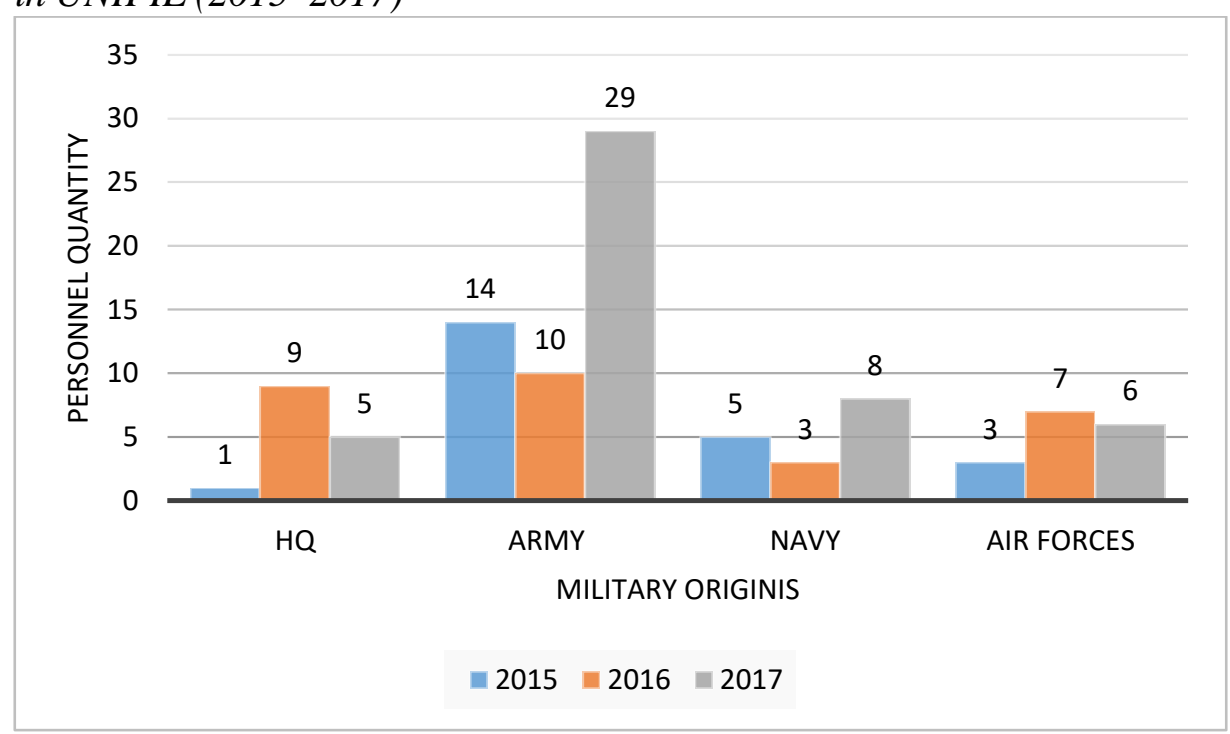

Army forces are dominating the composition. However, Vice Commander of Indonesia National Defense Force Peacekeeping Center clarified that it was just 
adjusted with the position requirements and it did not mean to give a privilege for army forces. From the above picture (Figure 3), it is obtained that the comparison ratio is 53:16:16 for army, navy, and air forces consecutively. As the quantity of Indonesian female peacekeepers is increasing in Lebanon, Indonesia is also the third biggest contributing country in sending female peacekeeper after Ghana and France. The proportion compared with global TCC in UNIFIL can be seen in Table 1 and Figure 4.

Table 1. Percentage of Indonesia's Contribution (Female) Compared with Global TCC in UNIFIL (Female)

\begin{tabular}{|l|c|c|c|}
\hline \multicolumn{1}{|c|}{ Year } & $\mathbf{2 0 1 5}$ & $\mathbf{2 0 1 6}$ & $\mathbf{2 0 1 7}$ \\
\hline Subject & 334 & 408 & 444 \\
\hline Total of UNIFIL Female Peacekeepers & 23 & 29 & 48 \\
\hline Indonesian Female Peacekeepers & $6.9 \%$ & $7.1 \%$ & $10.8 \%$ \\
\hline Percentage of Contribution
\end{tabular}

Figure 4. Proportion of Indonesian Female Peacekeepers in the Global TCC in UNIFIL

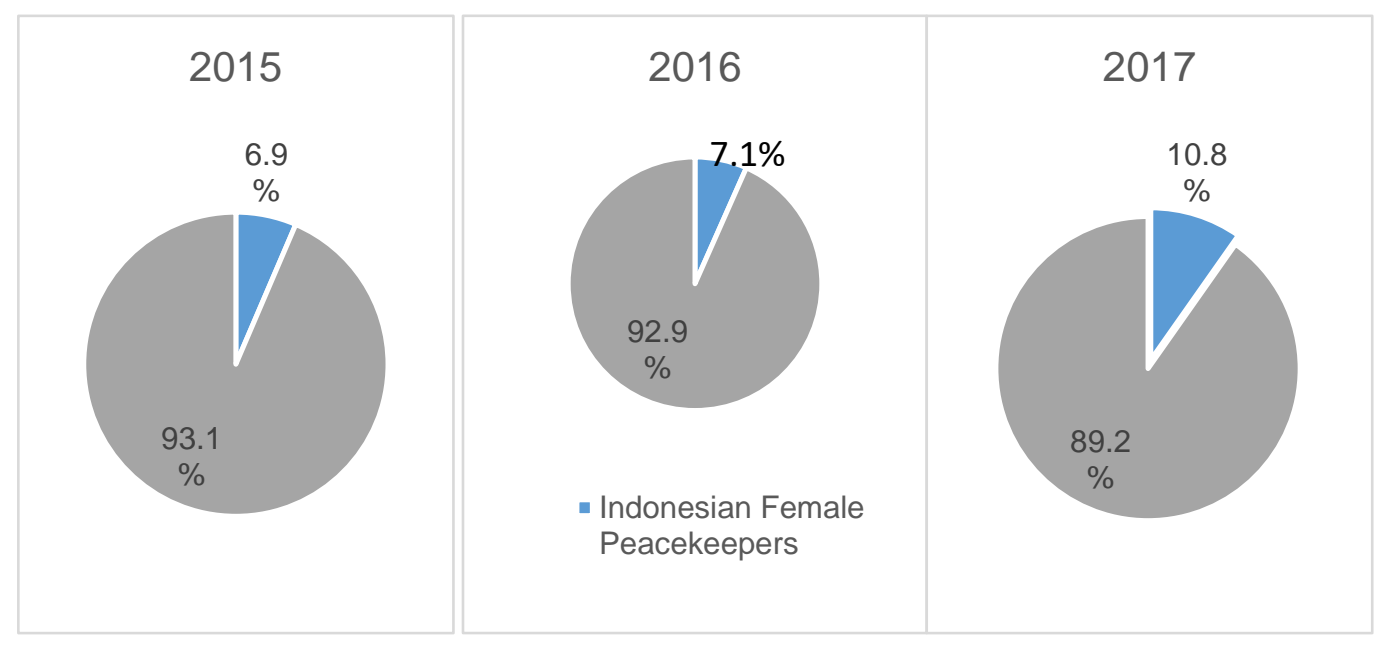

\section{Female Activities in Peacekeeping}

Indonesian female peacekeepers in UNIFIL worked mandatory under UNSC Resolution No. 1701. Their activities are associated with their position and job assignment. From distribution of position, four activities can be highlighted for Indonesian female peacekeepers. They are about Civil Military Cooperation (CIMIC), Military Outreach, Medic, and Logistic affairs. In an interview with Indonesian female peacekeepers, the presence of female in local society is more accepted, females able to open an access of information especially for victims of gender-based violence. Moreover, females are also able to give a certain support to empower other females (women and girls) and finally to create a gender-friendly mission. Therefore, it is expected that the mission could bring an inclusive and sustainable peace. 
In the development of gender perspective in peacekeeping, UNIFIL has newly established special team consisted of 21 female peacekeepers both from civilian and uniformed forces in 2016. The special team is "Female Assessment/ Analysis and Support Team" (FAST) (UNIFIL 2016). The team is trained and called from UNIFIL Contingent to support female existence in various sensitive and cultural situations. In UNIFIL itself, representation of uniformed female peacekeepers is only $3 \%$ and there are some military units and battalion which has no female personnel at all. FAST was established to provide an opportunity/open access for local women community to have a consultation with UNIFIL and to become an inclusive mission with regards to safety and security perspective. Indonesian female peacekeepers are part of this special team. While the first allfemale patrol was done in 2017 by 6 personnel from Ghana, Ireland, Italia, South Korea, Malaysia and Netherlands, Indonesia is not the first time who involved in the first all-female patrol (Badereddine and Ezzeddine 2018). However, it signifies that the mission has tried to embrace gender perspective and Indonesian female peacekeeper would be part of it while waiting for its turn.

Further, in term of military outreach program, Indonesian female peacekeeper was selected to be a spoke person in the program of community outreach (MCOU) in 2017. First Sergeant Etikasari visited public school in Aytarun with other UNIFIL peacekeepers including two personnel from Indonesia Head Sergeant Dian Rosdiana and Eliana as translator. FS Etikasari explained about Blue Line to the students and it was presented in an interactive way to attract the students (O'Sullivan 2017). This program is important to educate students regarding safety along the blue line in order to prevent violation of the UNSC resolution 1701.

The participation of Indonesian female peacekeepers also can be seen in medical and logistic affairs. In medical for example, Indonesian female peacekeeper concerned to the hygiene of mission area in Naqoura ${ }^{7}$. An interview with female army (2018) confirmed that she and her medical team helped to ensure good sanitation in order to provide convenience and hygiene environment. While in logistic affairs, Indonesian female peacekeeper helped to manage logistic supports started from accepting weekly report from each sector in UNIFIL regarding logistic, reviewing all activities and problems related to Mission Support Center Operations/Logistics Matters, coordinating and monitoring the movement convoy, coordinating with other supporting units, until reporting all the programs/ activities (Nuraeni 2016). From those activities, Indonesian female peacekeepers indicated an extensive interaction with fellow personnel in Contingent, other personnel from different countries, and local community. It has to be one of the ways to ensure the world that Indonesia committed to actively participate in sustainable peace.

Those activities were in line with three types of participation mentioned by Cohen and Uphoff (1980); these are participation in implementation, benefits, and evaluation. The participation of Indonesian female peacekeepers positively supported the implementation of task both under contingent and military staff. The research found that its participation was showing resource contributions as an

\footnotetext{
${ }^{7}$ Interview with Major Sarah Tidar in Bogor, Indonesia, 20 September 2018.
} 
international worker and contribute to the dissemination of information. In term of worker, Indonesian female peacekeepers were embedded to UN standard of procedures and administration routines that should be reported in daily, weekly and monthly. The procedures were important for their reference to follow up a certain condition at the mission and to make sure their safety and security during the mission. Then, in term of dissemination of information, Indonesian female peacekeepers have visited some public places to provide information related to the mission. It helped society to be aware of actual situation and condition, blue line function and restrictions, as well as traffic safety.

Participation of Indonesian female peacekeepers was also relevant to the term of benefits. Cohen and Uphoff (1980) stated that it can be seen in three areas such as material, social, and personal. Material benefits were obtained since female peacekeepers were also paid by the United Nations. Participation of Indonesian female peacekeepers in UNIFIL also could not be separated with their contribution in opening an access for health services, education and information. Local society appreciated the present of female peacekeepers in raising their awareness and keeping the peace conditions in a peaceful means. Further, benefits also obtained personally for Indonesian female peacekeepers. In the interview with female peacekeepers, they confirmed that they had a great opportunity to be "representative" of United Nations and Indonesia to collaborate and cooperate with other military and civil components in the mission. Through that opportunity, females are trained to respect cultures differences. A mission also trained females personally to be well manage, familiar with UN bodies, and had an experience to use international standard' equipment either information communication technology or the transportation. At the field, females stayed with other forces from different countries which at least made them frequently listen to different languages. In UNIFIL itself, apart from English, Arabic was also common to listen and learn.

Lastly, after females completed their task and backed to Indonesia, they contribute to evaluate the implementation of Indonesia's contribution at the mission. The research did not find prominent obstacles that hampered the implementation of tasks. However, it was noted during the interview with Indonesian female peacekeepers that delayed hand over among the staff was something that affected the new staff/troops had to find out their task's descriptions by their self. PMPP TNI conveyed that the delay was happened due to rotation problem and some administration matters that need to be arranged. They also expect that Indonesia could increase the quantity of female peacekeepers. Thus, Indonesia's participation could support the gender balance strategy.

\section{Conclusion}

Indonesian female peacekeepers participation in UNIFIL for the period of 2015-2017, was increasing in quantity every year. The total number of female peacekeepers deployed in UN mission during 2015-2017 was 134, and 100 personnel were deployed in Lebanon (UNIFIL). This quantity represented $74.6 \%$ 
of Indonesian female distribution around the world by 2015-2017. However, the number of Indonesian female peacekeepers was still limited in supporting UN mission. There were some obstacles in recruitment, mostly posted in Contingent and a small number in Headquarter, as military staff under various supporting unit activities, such as CIMIC, Community Outreach, Medical and Logistic affairs. Therefore, it needs to be considered a strategic policy related to female participation to support Indonesia's contribution in peacekeeping operations.

\section{Acknowledgments}

We would like to thank to Indonesia Defense University (Universitas Pertahanan Indonesia) for funding the research. We would also like to thank Indonesian Ministries (Ministry of Defense and Ministry of Foreign Affairs), Headquarter of Indonesia National Forces, and PMPP TNI who have shared their thoughts and data for this research. Finally, our special thanks goes to all Indonesian female peacekeepers who have performed outstanding contributions both for Indonesia and the global peace and security.

\section{References}

Allison S (2015) Are women better peacekeepers? These UN officers think so. The Guardian. Retrieved from: https://www.theguardian.com/world/2015/sep/17/womenbetter-peacekeepers-un-officers-think-so.

Anya A (2018) Low numbers Hamper Indonesia's pledge to send more women peacekeeper. The Jakarta Post. Retrieved from: http://www.thejakartapost.com/news/ 2018/06/25/low-numbers-hamper-indonesias-pledge-to-send-more-women-peacekee pers.html.

Badereddine S, Ezzeddine Z (2018) UNIFIL female assessment/analysis support team (FAST) patrols in Rmeish. Retrieved from: https://unifil.unmissions.org/unifil-fema le-assessmentanalysis-support-team-fast-patrols-rmeish.

Capie D (2016) Indonesia as an emerging peacekeeping power: norm revisionist or pragmatic provider? Contemporary Southeast Asia: A Journal of International and Strategic Affairs 38(1): 1-27.

Cohen J, Uphoff N (1980) Participation's place in rural development: seeking clarity through specificity. World Development.

Geuskens I (2014) Gender and militarism: analyzing the links to strategize for peace. The Hague: Women Peacemakers Program (WPP), May 24 Action Pack.

Lopes H (2011) Militarized masculinity in peacekeeping operations: an obstacle to gender mainstreaming. Background Paper Peacebuilding and Conflict Prevention Consultation Series, Peacebuild.

Miles MB, Huberman AM, Saldana J (2014) Qualitative data analysis: a methods sourcebook. $3^{\text {rd }}$ Edition. California: SAGE Publications.

Norad (2013) A framework for analysing participation in development. Report 1. Oslo: Norad Evaluation Department.

Nuraeni E (2016) Laporan Pelaksanaan Tugas JLOC OPSSO1 UNIFIL HQ Naqoura Lebanon. (Task Implementation Report Naqoura Lebanon). Bogor: PMPP TNI. 
O'Sullivan A (2017) "Mr. and Mrs. Blue Barrel" educate young children on blue line safety. Retrieved from: https://unifil.unmissions.org/\%E2\%80\%9Cmr-and-mrs-bluebarrel\%E2\% 80\%9D-educate-young-children-blue-line-safety.

PMPP TNI (2011) TNI dan Misi Pemeliharaan Perdamaian: Peran PMPP TNI dalam Menyiapkan Kontingen Garuda. (TNI and Peacekeeping Missions: The Role of PMPP TNI in Preparing Garuda Contingents). Jakarta: PMPP-TNI.

Pramasatya S (2015) Peran Penjaga Perdamaian Wanita dalam Proses Bina-Damai: Studi Kasus Operasi Perdamaian Monusco. (The role of women peacekeepers in the peacebuilding process: a case study of the Monusco peace operations). Indonesian Journal of International Studies 2(1): 51.

Schouten P, Dunham H (2012) Theory talk \#48: Cynthia Enloe on militarization, feminism, and the international politics of banana boats. Theory Talks, May. Retrieved from: http://www.theorytalks.org/2012/05/theory-talk-48.html.

UNIFIL (2016) New UNIFIL initiative to ensure gender perspective in host communities. Retrieved from: https://unifil.unmissions.org/new-unifil-initiative-ensure-genderperspective-host-communities.

United Nations (2002) Gender mainstreaming: an overview. New York: Office of the Special Adviser on Gender Issues.

United Nations (2003) Handbook on United Nations multidimensional peacekeeping operations. New York: United Nations.

United Nations (2006) UN military roles and responsibilities. Integrated Disarmament, Demobilization and Reintegration Standards Module.

United Nations (2008) United Nations peacekeeping operations principle and guidelines. New York: United Nations.

United Nations (2012) Brief introduction to UN peacekeeping. Civil Affairs Handbook. New York. Retrieved from: http://www.un.org/en/peacekeeping/documents/civilha ndbook/Chapter1.pdf.

United Nations (2018) Troop and police contributors. UN Peacekeeping, June. Retrieved from: https://peacekeeping.un.org/en/troop-and-police-contributors. 
